Materiales de Construcción

Vol. 68, Issue 330, April-June 2018, e157

ISSN-L: 0465-2746

https://doi.org/10.3989/mc.2018.03317

\title{
Ultrafine portland cement performance
}

\author{
C. Argiz $\bowtie$, E. Reyes, A. Moragues \\ Science and Technology of Building Materials. School of Civil Engineering, Technical University of Madrid, (Madrid, Spain) \\ $\triangle$ cg.argiz@upm.es
}

\begin{abstract}
By mixing several binder materials and additions with different degrees of fineness, the packing density of the final product may be improved. In this work, ultrafine cement and silica fume mixes were studied to optimize the properties of cement-based materials. This research was performed in mortars made of two types of cement (ultrafine Portland cement and common Portland cement) and two types of silica fume with different particle-size distributions. Two Portland cement replacement ratios of $4 \%$ and $10 \%$ of silica fume were selected and added by means of a mechanical blending method. The results revealed that the effect of the finer silica fume mixed with the coarse cement enhances the mechanical properties and pore structure refinement at a later age. This improvement is somewhat lower in the case of ultrafine cement with silica fume.
\end{abstract}

KEYWORDS: Portland cement; Silica fume; Compressive Strength; Hg Porosimetry; Thermal analysis.

Citation/Citar como: Argiz, C.; Reyes, E.; Moragues, A. (2018) Ultrafine portland cement performance. Mater. Construcc. 68 [330], e157 https://doi.org/10.3989/mc.2018.03317

RESUMEN: Prestaciones del cemento portland ultrafino. La densidad de empaquetamiento del producto final se puede mejorar cuando se mezclan varios conglomerantes y adiciones de diferente finura. En este trabajo se estudiaron varias mezclas de cemento ultrafino y humo de sílice para optimizar las propiedades de los materiales de base cemento. Esta investigación se realizó con morteros fabricados con dos tipos de cemento (cemento Portland ultrafino y cemento Portland común) y dos tipos de humo de sílice con diferentes tamaños de partícula. Se seleccionaron dos porcentajes de sustitución de cemento Portland por humo de sílice (4\% y 10\%) que se mezclaron mecánicamente. Los resultados revelaron que la mezcla del humo de sílice más fino con el cemento grueso mejora las propiedades mecánicas y el refinamiento de la distribución del tamaño de poro a edades avanzadas. Esta mejora de resistencias y reducción del tamaño de poro era menor en el caso del cemento ultrafino con el humo de sílice.

PALABRAS CLAVE: Cemento Portland; Humo de sílice; Resistencia a compresión; Porosimetría de Hg; Análisis térmico.

ORCID ID: C. Argiz (https://orcid.org/0000-0003-4519-872X); E. Reyes (https://orcid.org/0000-0002-1284-7335); A. Moragues (https://orcid.org/0000-0001-7819-3066)

Copyright: (C) 2018 CSIC. This is an open-access article distributed under the terms of the Creative Commons Attribution 4.0 International (CC BY 4.0) License.

\section{INTRODUCTION}

Portland cement-based materials, which have good mechanical and durable performances, form the basis of many civil structures and buildings located around the world. Unfortunately, given that the production of Portland cement is an energy-intensive process.
The carbon dioxide emission footprint produced by the cement industry is significant. For such a reason, it must be minimized. This has led to alternatives being examined that address a problem that persists (1). Such research involves significant scientific and engineering challenges. This has led to alternatives being examined that address a problem that' persists. 
Currently, one of the major trends in concrete technology entails the increase of cement fineness in producing concretes with improved mechanical properties. For a given water-to-cement (w/c) ratio, an lower average particle size generally results in an enhancement of the hydration reaction with improved early properties, such as a higher early strength. Published research has examined how high-performance concretes with relatively low w/c ratios and coarser cements may present an equivalent long-term performance to finer cements (2). This results in energy savings due to a reduction in grinding time. Another trend, partially in response to an increased focus on sustainability, entails an increase in the production of blended cements made from mineral by-products such as ground granulated blast-furnace slag, coal fly ash or silica fume. The use of some mentioned by-products not only decreases carbon dioxide emissions and energy cost but also leads to a more durable concrete due to pozzolanic or hydraulic properties. Ultrafine Portland cements combined with silica fume could offer one alternative type of cement capable of providing both technical and environmental advantages, thus increasing early age strength at the same time as maintaining long-term performance.

Two important physical parameters that affect cement performance are particle-size distribution and the specific surface area. Published research has shown that a wider particle-size distribution decreases water demand and increases packing density (3). In addition, a narrower particle-size distribution with an equal surface area leads to higher hydration rates (4). Other studies have suggested a nucleation and seeding effect of fine $\mathrm{SiO}_{2}$ on the hydration mechanisms and shown that silica fume markedly increases strength (5). Therefore, fine particles in mortars play three roles: filling capillary pores, reacting with calcium hydroxide to produce $\mathrm{C}-\mathrm{S}-\mathrm{H}$ gel (pozzolanic activity), and providing nucleation sites. The result of these three functions is a mortar with a pore size refinement $(3,4,6)$.

In particular, given that packing density may be increased by combining two or more components with different particle-size distributions, a mechanical strength enhancement resulting from the filler effect of fine constituents could be expected $(6,7)$. New concrete mix designs, like reactive powder concretes (RPCs) $(8,9)$, are based on such a concept.

Due to the results found in binder systems that contain ultrafine cement, new research that replaces normal grain sized Portland cement with ultrafine cement and silica fume is proposed. Generally, despite the considerable effect of the particle-size distribution on the strength properties of cementbased materials and the durability of mortar, very little work has been performed on ultra-fine cement. Therefore, the originality of this paper entails study of the influence of silica fume fineness on the properties of ultrafine Portland cement $(\mathrm{U})$ and common Portland cement (R).

This paper describes the influence of silica fume fineness on the properties of ultrafine Portland cement (U) and common Portland cement (R). The experimental campaign was carried out on standardized mortars that included compressive strength, mercury intrusion porosimetry (MIP) and thermogravimetric and derivative thermogravimetric analysis (TG/dTG) and resistivity.

\section{EXPERIMENTAL PROCEDURE}

\subsection{Materials}

A common Portland cement CEM I 52.5 R-SR 5 according to the European standard EN 197-1:2011 (10) with a specific surface area of $479 \mathrm{~m}^{2} / \mathrm{kg}$ and an ultrafine cement (CEM I 52.5 R-SR 3, Ultraval ${ }^{\mathbb{B}}$ ) with a specific surface area of $832 \mathrm{~m}^{2} / \mathrm{kg}$ were used. Two brands of silica fume (SF) were used as pozzolanic materials in this work. They were named SFF (supplied by FerroAtlantica, S.L., Spain) with a specific surface area of $21,892 \mathrm{~m}^{2} / \mathrm{kg}$ and termed SFN in this paper (supplied by Elkem, Norway) with a specific surface area of $28,200 \mathrm{~m}^{2} / \mathrm{kg}$. In addition, NORMASAND sand according to the European standard EN 196-1:2016 (11) and deionized water were mixed during the mortar preparation. A commercial polycarboxylate-based superplasticizer, Sika ViscoCrete 5720 (SP), with 36\% solid content and $1,090 \mathrm{~kg} / \mathrm{m}^{3}$ density, was employed. The chemical and mineralogical composition of CEM I 52.5 R-SR 5, ultrafine cement (CEM I 52.5 R-SR 3), SFF and SFN are shown in Table 1.

\subsection{Mix proportions}

Some blended cements were prepared by replacing $4 \%$ and $10 \%$ of cement weight with SFF and SFN. Two types of silica fume, again SFF and SFN, were mechanically blended. Details of mortar mix proportions with either CEM I 52.5 R-SR 5 (R) or ultrafine cement $(\mathrm{U})$ are shown in Table 2 . The waterbinder ratio w/b was 0.5 for the mixtures. Mortars were cast into $40 \times 40 \times 160 \mathrm{~cm}$ moulds, following the European standard EN 196-1:2016 (11). The samples were maintained for 24 hours in a chamber at $20^{\circ} \mathrm{C}$ and $95 \%$ of relative humidity. They were then demoulded and cured in water at $20 \pm 2^{\circ} \mathrm{C}$ until the required curing ages: seven and 28 days.

\subsection{Methods}

The compressive strength test was performed according to EN 196-1:2016 (11) at seven and 28 days curing time. The electrical resistivity test method is described in the Spanish standard UNE 839881:2008 (13). Mortar prisms (40 x 40 x $160 \mathrm{~mm})$ 
TABLE 1. Chemical and mineralogical composition of raw materials: CEM I 52.5 R-SR 5, ultrafine cement, SFF and SFN.

\begin{tabular}{|c|c|c|c|c|}
\hline Parameters (\%) & CEM I 52.5 R-SR 5 (R) & Ultrafine cement (U) & Silica fume (SFF) & Silica fume (SFN) \\
\hline $\mathrm{SiO}_{2}$ & 20.61 & 20.30 & 97.40 & 97.61 \\
\hline $\mathrm{Al}_{2} \mathrm{O}_{3}$ & 4.34 & 3.96 & 0.25 & 0.33 \\
\hline $\mathrm{Fe}_{2} \mathrm{O}_{3}$ & 2.49 & 1.28 & 0.28 & 0.11 \\
\hline $\mathrm{CaO}$ & 63.62 & 66.80 & 0.66 & 0.26 \\
\hline $\mathrm{MgO}$ & 2.21 & 1.54 & 0.22 & 0.43 \\
\hline $\mathrm{K}_{2} \mathrm{O}$ & 0.89 & 0.44 & 0.43 & 0.79 \\
\hline $\mathrm{Na}_{2} \mathrm{O}$ & 0.26 & 0.28 & 0.62 & 0.21 \\
\hline $\mathrm{SO}_{3}$ & 3.45 & 3.07 & 0.13 & 0.34 \\
\hline $\mathrm{TiO}_{2}$ & 0.25 & 0.12 & -- & -- \\
\hline $\mathrm{P}_{2} \mathrm{O}_{5}$ & 0.16 & --- & -- & -- \\
\hline $\mathrm{Cl}^{-}$ & 0.05 & --- & -- & -- \\
\hline Loss on ignition $\left(950^{\circ} \mathrm{C}\right)$ & 2.16 & 2.02 & 2.89 & 1.52 \\
\hline Insoluble residue & 0.90 & --- & -- & -- \\
\hline $\mathrm{C}_{3} \mathrm{~S}$ & 69.57 & 84.03 & & \\
\hline $\mathrm{C}_{2} \mathrm{~S}$ & 6.69 & 0.64 & & \\
\hline $\mathrm{C}_{3} \mathrm{~A}$ & 7.29 & 4.36 & & \\
\hline $\mathrm{C}_{4} \mathrm{AF}$ & 7.57 & 3.89 & & \\
\hline
\end{tabular}

*Insoluble residue was determined by the $\mathrm{Na}_{2} \mathrm{CO}_{3}$ method (EN 196-2:2013 (11).

TABLE 2. Mortar mix proportions.

\begin{tabular}{|c|c|c|c|c|c|}
\hline Sample code & Cement (g) & Water (g) & Sand (g) & Silica fume (g) & SP (g) \\
\hline $\mathrm{R}$ & 450 & 225 & 1350 & & \\
\hline R4SFF & 432 & 225 & 1350 & 18 & \\
\hline R10SFF & 405 & 225 & 1350 & 45 & 2 \\
\hline R10SFN & 405 & 225 & 1350 & 45 & 2 \\
\hline $\mathrm{U}$ & 450 & 225 & 1350 & & \\
\hline U4SFF & 432 & 225 & 1350 & 18 & \\
\hline U10SFF & 405 & 225 & 1350 & 45 & 2 \\
\hline U10SFN & 405 & 225 & 1350 & 45 & 2 \\
\hline
\end{tabular}

were tested at seven and 28 days by use of the two-electrode method. Open porosity and poresize distribution were determined at seven and 28 days by using the mercury intrusion porosimetry (MIP) technique in $\varnothing 12 \times 40 \mathrm{~mm}$ cylindrical samples, in a range of pore radius from 0.005 to $180 \mu \mathrm{m}$. Samples were oven-dried at $40 \pm 5^{\circ} \mathrm{C}$ for four days and then analyzed by means of a Micromeritics Autopore IV 9599 porosimeter. Mortar samples were also analyzed through thermogravimetric analysis, with the derivative thermogravimetric analysis (TG/dTG) curves being prepared by using thermal analyser (the Setaram brand, model Labsys Evo) equipment. The samples were heated from $40^{\circ} \mathrm{C}$ up to $1100^{\circ} \mathrm{C}$ with a scanning rate of

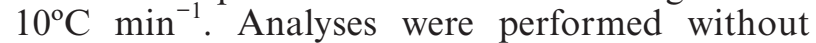
nitrogen gas flow in order to improve peak resolution (14).

\section{RESULTS AND DISCUSSION}

\subsection{Particle-size distribution}

Particle-size distribution of the two cements and two silica fumes used are presented in Fig. 1. Table 3 shows the particle-size distribution for both cements and silica fumes with the mean size value and some percentiles. The diameter mean size (Dv50) were 20.84 $\mu \mathrm{m}$ and $13.27 \mu \mathrm{m}$ for CEM I 52.5 R-SR 5 (R) and ultrafine cement $(\mathrm{U})$, respectively. The most frequently identified particle size was $0.6 \mu \mathrm{m}$ for silica fume supplied by Elkem (SFN). For silica fume supplied by FerroAtlantica (SFF) a trimodal particle-size distribution was found with three peaks at $60 \mu \mathrm{m}, 10 \mu \mathrm{m}$ and $0.5 \mu \mathrm{m}$. Typically, silica fume particle size is known to be less than $1 \mu \mathrm{m}$. Therefore, it is suggested that the original peak of $0.5 \mu \mathrm{m}$ decreases as a consequence of 
(a)

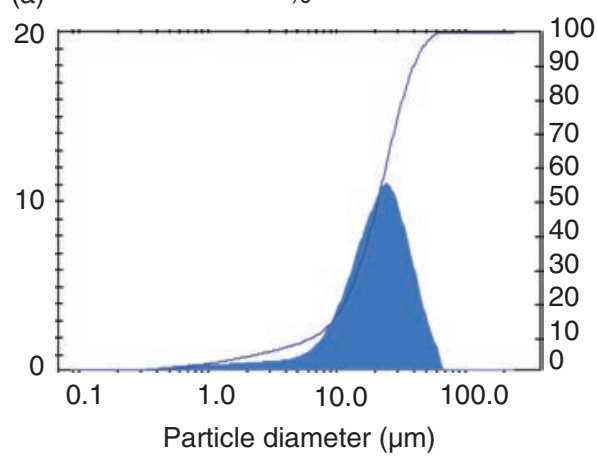

(c)

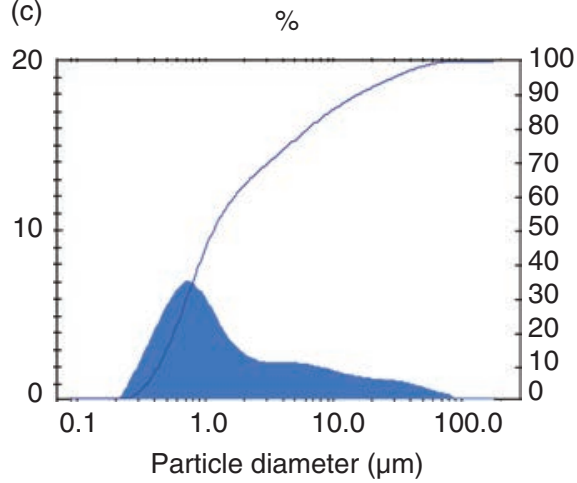

(b)

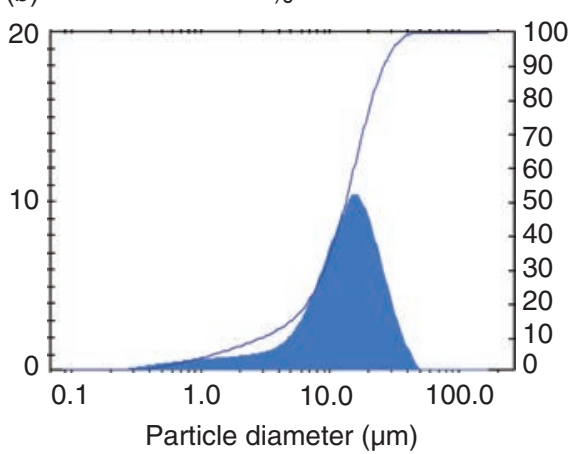

(d)

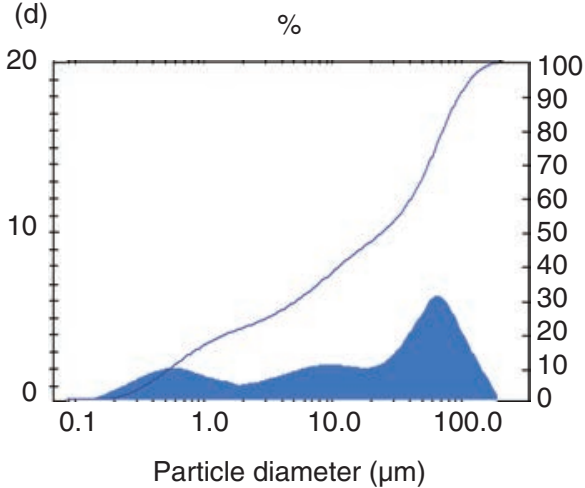

FIGURE 1. Particle-size distribution of raw materials; a) CEM I 52.5 R-SR 5 (R); b) ultrafine cement (U); c) SFN silica fume; d) SFF silica fume.

TABLE 3. Particle-size distributions for both cements and silica fumes.

\begin{tabular}{lccc}
\hline Sample code & Dv10 $(\boldsymbol{\mu m})$ & Dv(50( $\boldsymbol{\mu m})$ & Dv90 $(\boldsymbol{\mu m})$ \\
\hline R & 6.40 & 20.84 & 39.64 \\
U & 3.02 & 13.27 & 26.20 \\
SFN & 0.43 & 1.16 & 15.58 \\
SFF & 0.56 & 24.78 & 95.86
\end{tabular}

particle agglomeration (15). Particle-size distribution of binders and additions directly affects the physical properties of the cement-based materials (4). Thus, SFN with a continuous size distribution and lower average particle diameter is expected to perform better than SFF when mixed with both cements.

\subsection{Compressive strength}

The compressive strength tests results obtained for mortars at seven and 28 days are shown in Table 4 . The results are the average obtained from six testing samples.

The ultrafine cement (U) (specific area of 832 $\mathrm{m}^{2} / \mathrm{kg}$ ) has a compressive strength at seven days 38\% higher than CEM I 52.5 R-SR 5 (specific surface area of $479 \mathrm{~m}^{2} / \mathrm{kg}$ ). All the mortars made with the ultrafine cement (U) reached approximately the same value at seven days and no strength
TABLE 4. Compressive strength results (MPa) at seven and 28 days in mortar specimens.

\begin{tabular}{lcc}
\hline Sample code & 7days & 28days \\
\hline R & $47( \pm 1.5)$ & $62( \pm 1.0)$ \\
R4SFF & $55( \pm 0,8)$ & $60( \pm 1.4)$ \\
R10SFF & $49( \pm 0.9)$ & $60( \pm 1.3)$ \\
R10SFN & $60( \pm 1.3)$ & $76( \pm 0.7)$ \\
U & $65( \pm 1.0)$ & $68( \pm 0.9)$ \\
U4SFF & $62( \pm 0.8)$ & $67( \pm 1.2)$ \\
U10SFF & $64( \pm 1.5)$ & $66( \pm 1.3)$ \\
U10SFN & $65( \pm 1.1)$ & $76( \pm 1.2)$ \\
\hline
\end{tabular}

enhancement was found when $4 \%$ or $10 \%$ SFF was used. With regard to the $10 \%$ SFN mortars, a compressive strength increase of $12 \%$ was found at 28 days.

The normal-sized cement mortar $(\mathrm{R})$ with the finest silica fume (SFN) reached the same compressive strength at 28 days as the mortar with the finest cement and the same type of silica fume. Such a compressive strength was even higher than the value obtained with the ultrafine cement without silica fume.

The normal-sized cement mortar $(\mathrm{R})$ with the finest silica fume (SFN) compared with the reference 
mortar, without addition, showed a $20 \%$ compressive strength increase at 28 days. Bonavetti et al. (16) found the same increase at 28 days by using $10 \%$ of silica fume. Silica fume-cement mortars with $4 \%$ SFF and $10 \%$ SFF provided similar mechanical results at 28 days to the plain mortar. Therefore, mortars with $10 \%$ SFN gave compressive strength results $25 \%$ higher than those with 10\% SFF. This suggests that SFN is more effective with high silica fume replacement of cement, $10 \%$ in this work, than SFF.

These findings agreed with the results published in a paper by Poon et al. (17) that reported a $15 \%$ and $12 \%$ compressive strength increase at seven and 28 days, respectively, in concretes made with $10 \%$ of silica fume. Elahi et al. (18) found a compressive strength increase in concretes made of $7.5 \%$ silica fume at all the testing ages. They also found that replacements of $15 \%$ showed the highest compressive strength results at 28 and 90 days, though the compressive strength at three and seven days was lower than the value of the plain concrete or that with $7.5 \%$ of silica fume. In agreement with Elahi et al. (18), a 17\% increase in the compressive strength at 28 days was found when $7.5 \%$ of silica fume SFN was added to the CEM I $42.5 \mathrm{~N}$. In the present research, a $17 \%$ increase in the compressive strength at seven days in mortars with 4\% SFF replacement of the CEM I 52.5 R-SR $5 \mathrm{R}$ was found.

Mazloom et al. (19) studied replacements of silica fume $(0,6,10$ and $15 \%)$ in high-performance concrete. They observed at 28 days a compressive strength increase of $12 \%$ with a $6 \%$ silica fume replacement $\left(\mathrm{SSA}=14,000 \mathrm{~m}^{2} / \mathrm{Kg}\right)$. This improvement reached $16 \%$ with $10 \%$ silica fume. In addition, Senhadji et al. (20) found the highest compressive strength at 28 days, though the compressive strength results for two days and seven days were quite similar.

The mix made with the normal-sized cement (R) and the finest silica fume (SFN) leads to a more significant compressive strength enhancement than the mix made with the finest sized cement (U) with SFN. This would be attributed to the influence of the particle-size distribution discussed by Sanjuán et al. (3). They found that the highest compressive strength was not always reached with the finest silica fume. Accordingly, there was a different effect on the particle-size distribution. A wider particlesize distribution improved the packing density. As a result of the greater compactness and the lower water demand caused, the strength is improved (21).

\subsection{Electrical resistivity}

Electrical resistivity results measured in mortars at seven and 28 days are shown in Fig. 2. These values increased with the silica fume amount in the mortar, leading to a durability improvement.

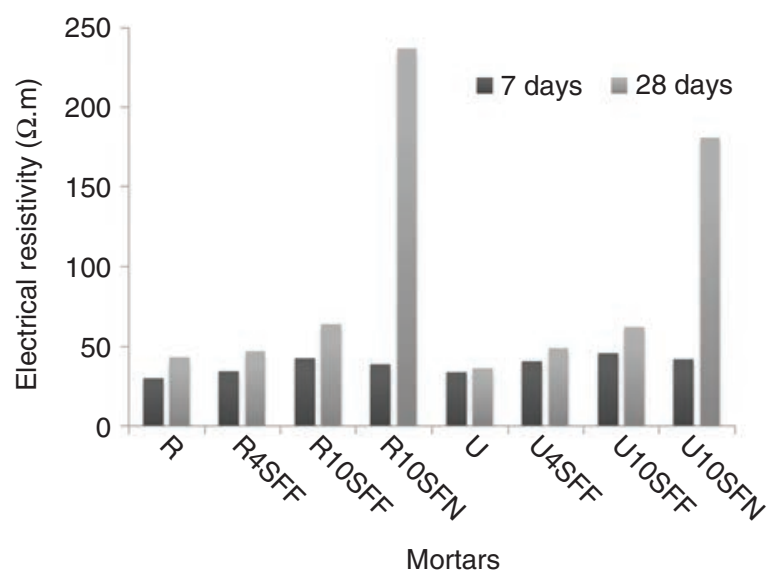

FIgURE 2. Resistivity of mortar prisms at seven and 28 days.

Different amounts of SFF added to the ordinary Portland cement or to the ultrafine cement $(4 \%$ and $10 \%$ ) resulted in significant improvements. When $4 \%$ of SFF was mixed with $\mathrm{R}$ cement, electrical resistivity at 28 days was improved by about $30 \%$ with regard to the finest one ( $\mathrm{U}$ cement). This value was even higher (about $43 \%$ ) when $10 \%$ of SFF is mixed. However, compressive strengths were lower than those of the finest cement (U). The most notable improvement was found in the normal-sized cement mortar (R) mixed with the finest silica fume (SFN). Thus, SFN was shown to exhibit much finer particle sizes and higher pozzolanic reactivity than SFF. Accordingly, it could act more effectively as a filler, pozzolan and nucleation seeds $(2,6,8)$. On the contrary, some kinds of silica fume such as SFF are often presented in an agglomerated form with a final grain size from $0.1 \mu \mathrm{m}$ to as high as $100 \mu \mathrm{m}$ due to their high specific surface area (15).

Amorphous silica reacts with calcium hydroxide formed from the hydration of calcium silicates. The rate of the pozzolanic reaction is proportional to the surface area available for reaction. Therefore, it was faster for the finer silica fume (SFN) and the R cement.

\subsection{Mercury intrusion porosimetry (MIP)}

Total porosity, pore-size distribution and cumulative intruded volume were determined at seven and 28 days by means of mercury intrusion porosimetry (MIP). Fig. 3 shows the total porosity results. Mortar porosity affects physical properties, mechanical strength and durability. As expected, total porosity decreased from seven to 28 days in both cements, $\mathrm{R}$ and $\mathrm{U}$.

All the mortars made with the finest cement (U) presented the lowest porosity at both ages. These data were in agreement with the compressive strength data. In this group of mortars, the replacement of $4 \%$ or $10 \%$ of SFF led to a slight increase in 


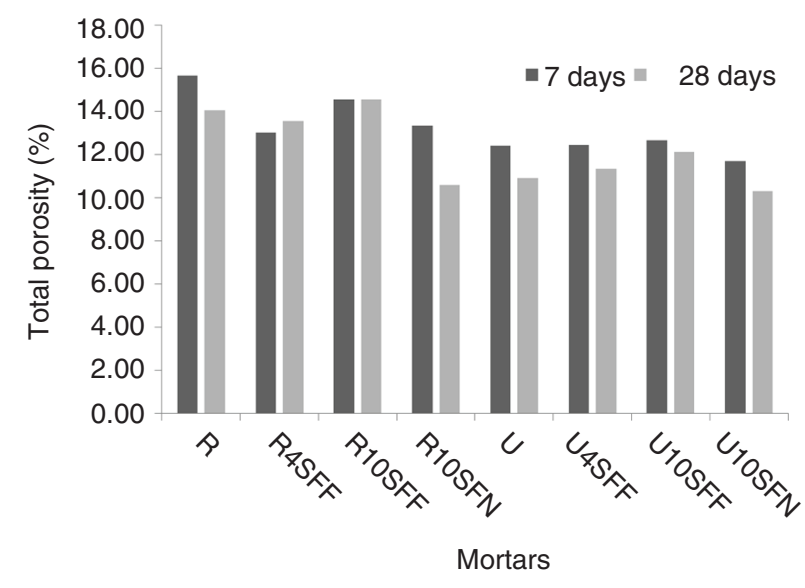

Figure 3. Total porosity of mortars at seven and 28 days (\%).

total porosity at 28 days with regard to the mortar with the finest cement (U) without addition.

As explained in the introduction, fine particles play three roles: filling capillary pores, reacting with calcium hydroxide to produce $\mathrm{C}-\mathrm{S}-\mathrm{H}$ gel (pozzolanic activity), and providing nucleation sites.

With regard to the R4SFF mortar, it was observed that the total porosity slightly increased from $12.98 \%$ at seven days to $13.55 \%$ at 28 days, although $4 \%$ of variation is insignificant. In parallel, with the hydration process, a $34 \%$ decrease of $\mathrm{Ca}(\mathrm{OH})_{2}$ was monitored (from $0.83 \%$ at seven days to $0.55 \%$ at 28 days). Therefore, the combination of these two opposite processes gave as a result a compressive strength and electrical resistivity increase. An increase in the amount of SFF from 4\% to $10 \%$ in the R cement mortars leads to a decrease in compressive strength at seven days, while at 28 days the values remain constant.

A total porosity increase and a reduction of cement hydration products and $\mathrm{Ca}(\mathrm{OH})_{2}$ content was found in both curing times. As a result of the combination of these factors, a compressive strength reduction was reached.

When the SFF amount was increased from $4 \%$ to $10 \%$ in U cement mortars, the compressive strength at both curing times was similar in each case. In addition, total porosity and $\mathrm{Ca}(\mathrm{OH})_{2}$ content were also similar.

Fig. 4 shows the total volume of mercury intruded into the sample versus the pore diameter, which was another indicator of the porosity of the sample. It was observed that the intruded mercury in silica fume mortars with $10 \%$ SFN of replacement of $\mathrm{U}$ cement exhibited a slight reduction in porosity (about 5\%) at 28 days.

The porosity obtained in the mortars with CEM I 52.5 R SR-5 and SFF were similar to those of the plain mortars at 28 days. By contrast, SFN reduced by about $25 \%$ the plain mortar porosity, with it being lower than that of a plain mortar made of $U$ cement. In the case of mortars made with SFF and the normal-sized Portland cement, R, a significant total porosity decrease was found with $4 \% \mathrm{SFF}$, but not with $10 \%$ SFF. Once again, it is confirmed that higher levels of SFF could not only fail to improve the mortar performance but also lead to a worsening of it. Thus, the total porosity decrease was only evident with 4\% SFF when the normal fineness cement (R) was employed. This showed that more than $4 \%$ SFF was ineffective in enhancing the mechanical properties of common Portland cement.

Fig. 5 and Fig. 6 present the pore-size distribution, where the pores are subdivided into small capillary pores $(5<\varnothing<10 \mathrm{~nm})$, average capillary pores $(10<\varnothing<50 \mathrm{~nm})$, large capillary pores $\left(50<\varnothing<10^{4} \mathrm{~nm}\right)$ and macropores $\left(\varnothing>10^{4} \mathrm{~nm}\right)$. Most of the ionic transport through the concrete took place through the capillary pores $10 \mathrm{~nm}<\varnothing<10 \mu \mathrm{m}$, whereas the gel pores practically did not contribute to transport (21). It was obvious that the SFN adition to CEM I 52,5R SR-5 promoted the highest reduction of the large capillary pores $(50<\varnothing<10 \mathrm{~nm})$ and porosity shifted toward small pores $(5<\varnothing<10 \mathrm{~nm})$. CEM I 52,5R SR-5 with SFN has produced an important pore refinement stronger than that given by the $\mathrm{U}$ cement alone or with SFN which had a considerable impact on durability.

\subsection{Thermogravimetric/derivative thermogravimetric analysis (TG/dTG)}

Table 5 shows the loss of weight in percentage (TG) in the range $\sim 140^{\circ} \mathrm{C}-400^{\circ} \mathrm{C}$ related to the water released from the hydrated phases, such as the following: hydrated calcium silicates (C-S-H), ettringite $(\mathrm{AFt})$, calcium aluminates and silicoaluminate hydrates (C-A-H and C-A-S-H), as well as monosulfoaluminates (AFm). The mass loss in the range $\sim 400^{\circ} \mathrm{C}-550^{\circ} \mathrm{C}$ was attributed to the dehydroxylation of water from the portlandite. At seven days, silica fume addition to R cement enhanced the C-S-H gel formation. The loss of hydrated phases increased from $1.87 \%$ to $2.43 \%$ with $4 \%$ SFF, but reached only $2.07 \%$ with $10 \%$ SFF. In the case of the mortar with $10 \% \mathrm{SFN}$, it reached the highest increase of $2.52 \%$. The group of pastes with U cement showed similar hydrated phases amounts than that of the reference mortar at an early age.

The enhancement of cement hydration during the first eight hours by the presence of silica fume was also found by Huang and Fedman (23) and Langan et al. (24). The reason for the increased rate in the first few hours of hydration was believed to be the enhanced precipitation of hydration products on the surface of silica fume particles, which possibly served as nucleation sites for cement hydration products in the pore space $(3,7)$. On the contrary, some kinds of silica fume, as SFF, are often in an agglomerated form with grain size from $0.1 \mu \mathrm{m}$ to 


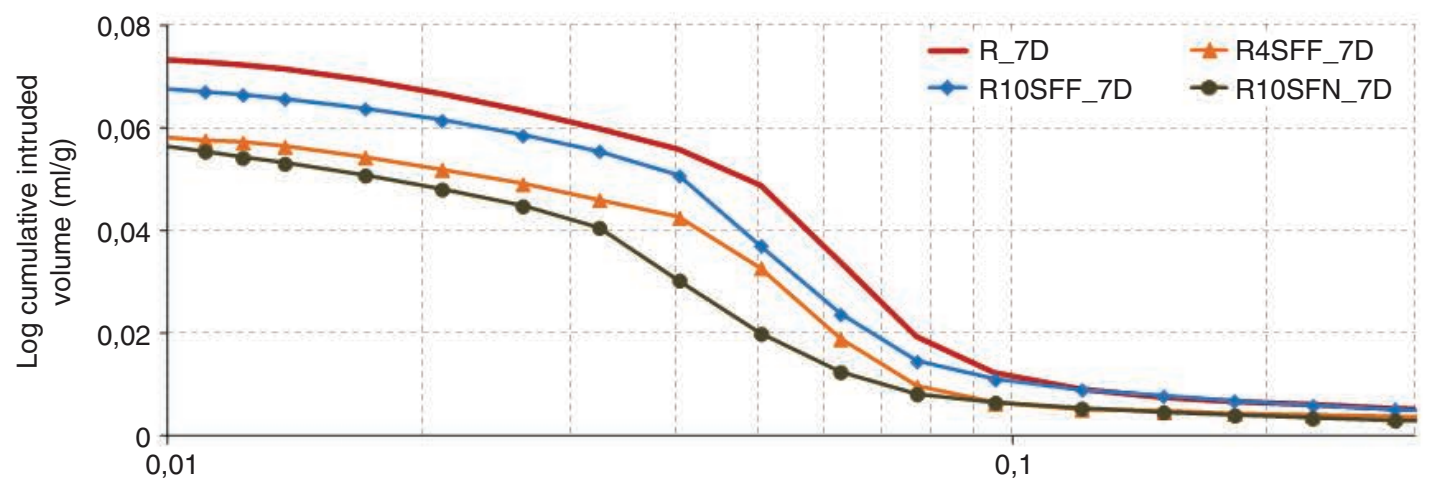

Pore diameter $(\mu \mathrm{m})$

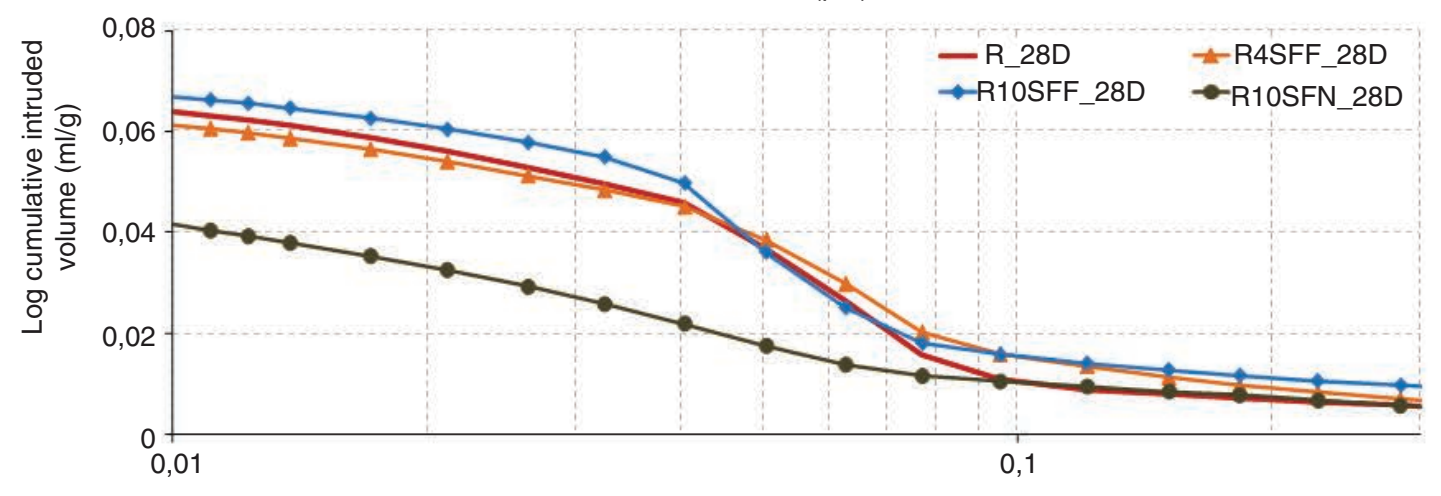

Pore diameter $(\mu \mathrm{m})$

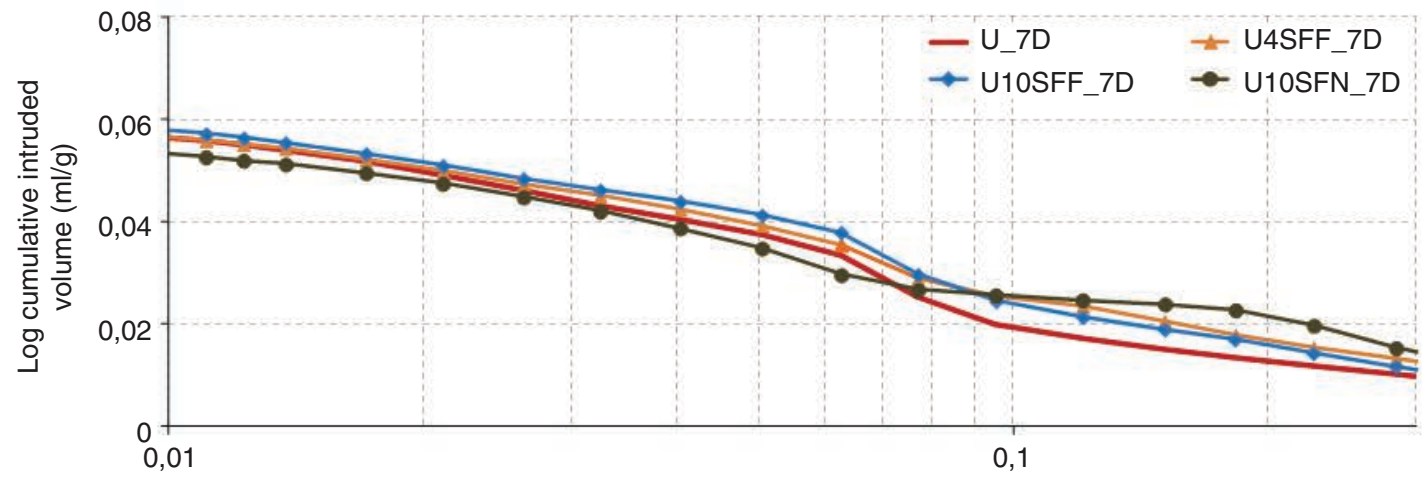

Pore diameter $(\mu \mathrm{m})$

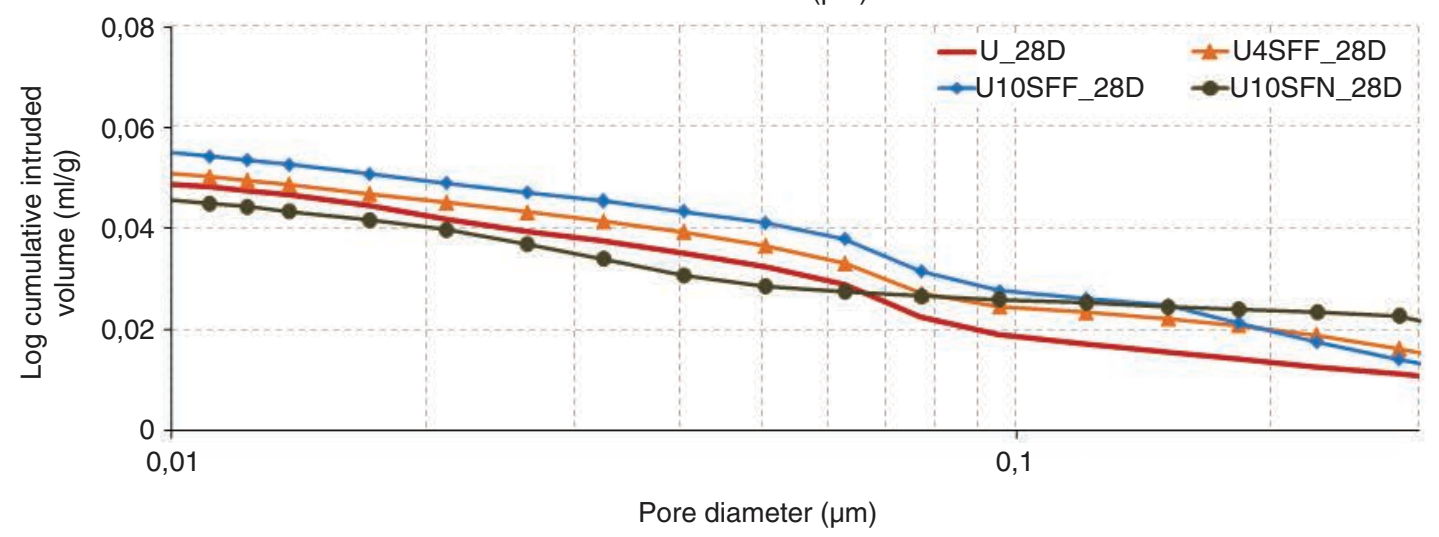

FIGURE 4. Logarithmic cumulative intrusion volume of mortars at seven and 28 days. 


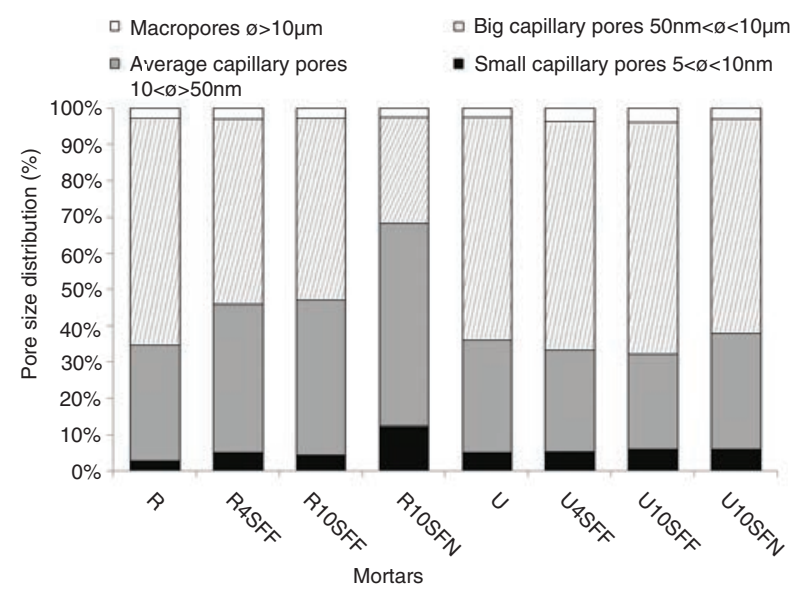

Figure 5. Pore-size distribution at seven days.

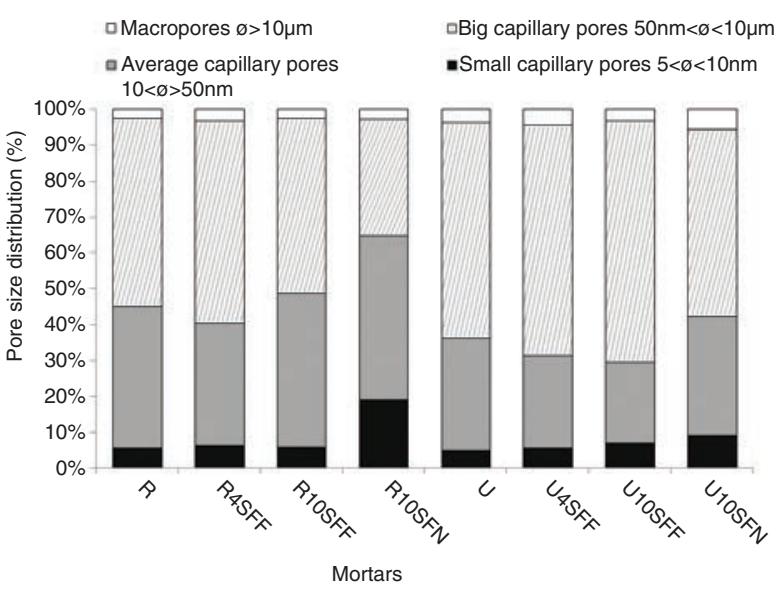

Figure 6. Pore-size distribution at 28 days.

$100 \mu \mathrm{m}$ due to their high specific surface areas (15) and are unable to serve such purpose.

From seven days of curing, the hydration of mortars with silica fume was almost completed. The amount of hydrated phases for the blended mortars with silica fume was of a lower value with regard to the reference mortar at 28-days, except for the mixes with $10 \%$ SFN for both cements, $\mathrm{R}$ and $\mathrm{U}$. The increase in the amount of hydrated phases, in comparison with the reference mortar, was always below $6 \%$ for both types of cements. Therefore, the $20 \%$ increment in the compresive strength at 28 days with $10 \% \mathrm{SFN}$ added to $\mathrm{R}$ cement could not be atributed only to amount of hydrated phases.

The portlandite content is the result of a combined process: cement hydration (that generates portlandite) and a pozzolanic reaction (that consumes portlandite). Reference mortars exhibited an increase of portlandite from seven to 28 days as a result of the Portland cement hydration evolution. The pozzolanic reaction was shown in blended cements by increasing portlandite consumption from seven to 28 days.

At early ages, hydration is also shown by the higher amount of portlandite found in the blended cements. The pozzolanic reaction was only noticeable with an SFN addition, which had the higher specific surface area. However, at 28 days, the portlandite amount moved from $0.77 \%$ (reference mortar) to $0.34 \%(10 \% \mathrm{SFN})$, that is to say, a decrease of $54 \%$ in comparison with the plain mortar. Nevertheless, the same addition to finer cement (U) led to only $30 \%$ of portlandite consumption.

It could be said that the compressive strength increase in $10 \%$ SFN cement was mainly due to a strengthening of the hydrated cement paste and aggregate bond (Table 1). This was due to the conversion of calcium hydroxide, which tends to form on the surface of the aggregate, into calcium silicate hydrate. This process was a result of the portlandite dissolution which reacted with the reactive silica forming C-S-H gel (Table 5). This enhanced the formation of a denser and homogeneous microstructure in the interfacial zone and contributed to pore refinement. This denser microestructure is observed in $10 \% \mathrm{SFN}+\mathrm{R}$ cement mortars. The increase in compressive strength when $10 \%$ SFN was added to $\mathrm{R}$ cement was due to the combination of the aforementioned two factors, capillary pore filling and hydration and pozzolanic reactions enhancement. With regard to the filling effect, it is necessary to consider not only the size of the individual particles but also the particle-size distribution (3). Taking this into account, the finest silica fume SFN mixed with the cement having the largest particles (R), led to a wider particle-size distribution. This mortar had 20\% less total porosity than the reference one (Fig. 5 and Fig. 6). Moreover, the amount of small capillary pores $(5<\varnothing<10 \mathrm{~nm})$ was three times greater than that of the reference mortar.

\section{CONCLUSIONS}

The influence on the properties of blended cements strongly depended on both the particle-size distribution of the silica fume and the cement.

The most significant improvements, both in mechanical strength and durability parameters at 28 days, were found when the difference in sizes was larger, that is to say, the mix of the normal sized Portland cement (R) and the finest silica fume (SFN). Accordingly, a wider particle-size distribution promoted a lower porosity, improved packing density (and thus compactness) and provided higher compressive strength and electrical resistivity of the mortars. The improvement in strength was related to the pore refinement due to the pozzolanic reaction and the filler and packing effect of finer particles in the mixture, along with a modest increase of 
TABLE 5. Weight loss of hydrated phases and portlandite from TG curves.

\begin{tabular}{lcccc}
\hline & Weight loss hydrated phases $\left(\right.$ range $\left.\mathbf{1 4 0}^{\mathbf{0}} \mathbf{C}-\mathbf{4 0 0}^{\mathbf{0}} \mathbf{C}\right) \mathbf{( \% )}$ & \multicolumn{2}{c}{ Weight loss for portlandite peaks $(\mathbf{\%})$} \\
\hline R & 7 days & 28 days & 7 days & 28 days \\
R4SFF & 1.87 & 2.93 & 0.67 & 0.77 \\
R10SFF & 2.43 & 2.81 & 0.83 & 0.55 \\
R10SFN & 2.07 & 2.50 & 0.68 & 0.51 \\
U & 2.52 & 3.12 & 0.58 & 0.34 \\
U4SFF & 2.54 & 2.68 & 0.98 & 1.03 \\
U10SFF & 2.48 & 2.65 & 0.92 & 0.90 \\
U10SFN & 2.37 & 2.69 & 0.96 & 0.91 \\
\hline
\end{tabular}

the C-S-H gel. These results were better than those obtained by using ultrafine cement alone.

At early ages (seven days), the hydration reaction was significantly enhanced when any type of silica fume was mixed with the normal-sized cement (R). The best results were obtained with the finest silica fume. On the contrary, the ultra-fine cement (U) had good mechanical properties at seven days. In this case, silica fume addition did not enhance its compressive strength, though it did so to a modest extent in the case of the finest addition.

It was also noticeable that the mixture of the normal sized cement $(\mathrm{R})$ and the greatest sized silica fume (SFF), even added in low ratios, improved durability properties that exceeded the ultra-fine cement. This could be particularly important for the increase in service life of structures and cost reduction, even though in terms of compressive strength the differences are insignificant.

\section{ACKNOWLEDGEMENTS}

The authors gratefully acknowledge the financial support provided by the Ministry of Economy and Competitiveness of Spain by means of the Research Fund Project MAT2013-48009-C4-4-P.

\section{REFERENCES}

1. Sanjuán, M.A.; Menéndez, E.; Argiz ,C.; Moragues, A. (2016) Coal bottom ash research program focused to evaluate a potential portland cement constituent. In: Proceedings of II International Conference on Concrete Sustainability. Madrid, Spain, June, 532-543.

2. Bentz, D.P.; Haecker, C.J. (1999) An argument for using coarse cements in high performance concretes. Cem. Concr. Res. 29[4], 615-618. https://doi.org/10.1016/ S0008-8846(98)00201-4

3. Sanjuán, M.A.; Argiz, C.; Gálvez, J.C.; Moragues, A. (2015) Effect of silica fume fineness on the improvement of Portland cement strength performance. Constr. Build. Mater. 96, 55-64. https://doi.org/10.1016/j.conbuildmat.2015.07.092

4. Kuhlmann, K.; Ellerbrock, H.G.; Sprung, S. (1985) Particle-size distribution and properties of cement. Part I: Strength of portland cement. ZKG International CementLime-Gypsum. Edition B. 38[4], 169-178.
5. Thomas, J.J.; Jennings, H.M.; Chen, J.J. (2009) Influence of Nucleation Seeding on the Hydration Mechanisms of Tricalcium Silicate and Cement. J. Phys. Chem. C. 113 [11], 4327-4334. https://doi.org/10.1021/jp809811w

6. Goldman, A.; Bentur, A. (1993) The influence of microfillers on enhancement of concrete strength. Cem. Concr. Res. 23 [4], 962-972. https://doi.org/10.1016/0008-8846(93)90050-J

7. Feng, N.Q.; Shi, Y.X.; Hao, T.Y. (2000) Influence of ultrafine powder on the fluidity and strength of cement paste. $\mathrm{Adv}$. Cem. Res. 12 [3], 89-95. https://doi.org/10.1680/adcr.2000.12.3.89

8. Roux, N.; Andrade, C.; Sanjuán, M. (1996) Experimental Study of Durability of Reactive Powder Concretes. J. Mater. Civ. Eng. 8 [1], 1-6. https://doi.org/10.1061/ (ASCE)0899-1561(1996)8:1(1)

9. Fernández, A.; Alonso, M.C.; García -Calvo, J.L.; Lothenbach, B. (2016) Influence of the synergy between mineral additions and Portland cement in the physicalmechanical properties of ternary binders. Mater. Construcc. 66 [324], October- December e097. https://doi.org/10.3989/ mc.2016.10815

10. EN 197-1:2011 Cement - Part 1: Composition. specifications and conformity criteria for common cements.

11. EN 196-1:2016 Methods of testing cement - Part 1: Determination of strength. European Committee for Standardization (CEN). Brussels.

12. EN 196-2:2013 Method of testing cement. Chemical analysis of cement.

13. UNE 83988-1:2008 Concrete durability. Test methods. Determination of the electrical resistivity. Part 1: Direct test (reference method). AENOR. Madrid.

14. Tobón, J.I.; Payá, J.; Borrachero, M.V.; Soriano, L.; Restrepo, O.J. (2012) Determination of the optimum parameters in the high resolution thermogravimetric analysis (HRTG) for cementitious materials. J. Therm. Anal. Calorim.107 [1], 233-239. DOI: 10.1007/s10973-010-0997-0

15. Kong, D.Y.; Du, X.F.; Wei, S.; Zhang, H.; Yang, Y.; Shah, S.P. (2012) Influence of nano-silica agglomeration on microstructure and properties of the hardened cementbased materials. Constr. Build. Mater. 37, 707-715. https:// doi.org/10.1016/j.conbuildmat.2012.08.006

16. Bonavetti, V.L.; Castellano, C.; Donza, H.; Rahhal, V.F.; Irassar, E.F. ((2014) Cement with silica fume and granulated blast-furnace slag: strength behavior and hydratation. Mater. Construcc. 64 [315], July-September e25 https://doi. org/10.3989/mc.2014.04813

17. Poon, C.S.; Kou, S.C.; Lam, L. (2006) Compressive strength chloride diffusivity and pore structure of high performance metakaolin and silica fume concrete. Constr. Build. Mater. 20 [10], 858-865. https://doi.org/10.1016/j. conbuildmat.2005.07.001

18. Elahi, A.; Basheer, P.A.M.; Nanukuttan, S.V.; Khan, Q.U.Z. (2010) Mechanical and durability properties of high performance concretes containing supplementary cementitious materials. Constr. Build. Mater. 24 [3], 292299. https://doi.org/10.1016/j.conbuildmat.2009.08.045 
19. Mazloom, M.; Ramezanianpour, A.A.; Brooks, J.J. (2004) Effect of silica fume on mechanical properties of high-strength concrete. Cem. Concr. Compos. 26 [4], 347-357. https://doi.org/10.1016/S0958-9465(03) $00017-9$

20. Senhadji Y, Escadeillas G, Mouli M, Khelafi H, Benosman. (2014) Influence of natural pozzolan silica fume and limestone fine on strength acid resistance and microstructure of mortar. Powder Technol. 254, 314-323. https://doi. org/10.1016/j.powtec.2014.01.046

21. Wang, A.Q.; Zhang, C.Z.; Zhang, N.S. (1999) The theoretic analysis of the influence of the particle-size distribution of cement system on the property of cement. Cem.
Concr. Res. 29 [11], 1721-1726. https://doi.org/10.1016/ S0008-8846(99)00148-9

22. Mahmoud, S.; Reyes, E.; Moragues, A. (2010) Evolution of microstructure and mechanical behavior of concretes utilized in marine environments. Mater. Des. 31[7], 3412-3418. https://doi.org/10.1016/j.matdes.2010.01.045

23. Huang, C.Y.; Feldman, R.F. (1985) Hydration reactions in portland cement-silica fume blends. Cem. Concr. Res. 15[4], 585-592. https://doi.org/10.1016/0008-8846(85)90056-0

24. Langan, B.W.; Weng. K.; Ward, M.A. (2002) Effect of silica fume and fly ash on heat of hydration of Portland cement. Cem. Concr. Res. 32[7], 1045-51. https://doi.org/10.1016/ S0008-8846(02)00742-1 